\title{
Defining the Minority-Preferred Candidate Under Section 2
}

\author{
Sushma Soni
}

Section 2 of the Voting Rights Act ${ }^{1}$ guarantees the equal opportunity to all citizens, regardless of their race or color, "to participate in the political process and to elect representatives of their choice."2 According to the legislative materials accompanying section 2 , courts could consider a range of factors $^{3}$ as probative of a vote dilution claim. ${ }^{4}$ In Thornburg v. Gingles, ${ }^{5}$

1. 42 U.S.C. $§ 1973$ (1982).

2. Id. Section 2, as amended, states in full:

Sec. 2 (a) No voting qualification or prerequisite to voting or standard, practice, or procedure shall be imposed or applied by any State or political subdivision in a manner which results in a denial or abridgement of the right of any citizen of the United States to vote on account of race or color, or in contravention of the guarantees set forth in section $1973 \mathrm{~b}(\mathrm{f})(2)$ of this title, as provided in subsection (b).

(b) A violation of subsection (a) of this section is established if, based on the totality of circumstances, it is shown that the political processes leading to nomination or election in the State or political subdivision are not equally open to participation by members of a class of citizens protected by subsection (a) of this section in that its members have less opportunity than other members of the electorate to participate in the political process and to elect representatives of their choice. The extent to which members of a protected class have been elected to office in the State or political subdivision is one circumstance which may be considered: Prozided, That nothing in this section establishes a right to have members of a protected class elected in numbers equal to their proportion in the population.

3. S. ReP. No. 417, 97th Cong., 2 d Sess. 28-29, reprinted in 1982 U.S. Code Cong. \& Admin. News 177, 206-07, which accompanied the bill amending $\S 2$, noted seven typical factors and two additional factors to be considered probative of a $\S 2$ violation:

1. the extent of any history of official discrimination in the state or political subdivision that touched the right of the members of the minority group to register, to vote, or otherwise to participate in the democratic process;

2 . the extent to which voting in the elections of the state or political subdivision is racially polarized;

3. the extent to which the state or political subdivision has used unusually large election districts, majority vote requirements, anti-single shot provisions, or other voting practices or procedures that may enhance the opportunity for discrimination against the minority group;

4. if there is a candidate slating process, whether the members of the minority group have been denied access to that process;

5. the extent to which members of the minority group in the state or political subdivision bear the effects of discrimination in such areas as education, employment and health, which hinder their ability to participate effectively in the political process;

6. whether political campaigns have been characterized by overt or subtle racial appeals;

7. the extent to which members of the minority group have been elected to public office in the jurisdiction.

Additional factors that in some cases have had probative value as part of plaintiffs' evidence to establish a violation are:

whether there is a significant lack of responsiveness on the part of elected officials to the particularized needs of the members of the minority group.

whether the policy underlying the state or political subdivision's use of such voting qualification, prerequisite to voting, or standard, practice or procedure is tenuous. 
however, the Supreme Court limited the list of relevant factors when it articulated the standard for establishing a voting rights violation under the newly-amended section 2. In an effort to pull order out of litigation chaos, the Court held that a plaintiff must meet a new test of discriminatory results in order to prove her vote dilution claim. Through this test, the Court intended to rein in the discretion afforded by section 2 , while remaining consistent with the legislative intent behind the amendments. The Court accomplished these objectives by elevating racially polarized voting ${ }^{6}$ to the top of a new hierarchy of proof-a standard specifically intended to ease the plaintiff's burden of proof.

Although the opinion of the Court delineated the criteria for a vote dilution claim, the Justices failed to agree on several crucial definitions. The most provocative term left undefined was what section 2 describes as the "representative[ ] of . . . choice," or what the opinion describes as "the minority's preferred candidate." By creating a standard but leaving the terms open to conflicting definitions, the Court has not only created an unexpectedly circular method of proof, but has also allowed the various circuits to reach independent, inconsistent conclusions as to the meaning of the value-laden term "minority-preferred." Such a lack of consistency

4. Vote dilution in violation of $\S 2$ occurs when a minority group's voting strength is minimized or cancelled out by a discriminatory practice. Whitcomb v. Chavis, 403 U.S. 124, 143 (1971). Common forms of vote dilution include racial gerrymandering of districts and at-large or multimember electoral systems. On racial gerrymandering, see Comment, The Results Test of Amended Section 2 of the Voting Rights Act: An Examination of the Senate Report Factors, 54 Miss. L.J. 289, 308 n.133 (1984) [hereinafter Comment, The Results Test]. In an at-large electoral system, voters cast ballots for all contested seats rather than for a single representative for their district, thus submerging the votes of any particular geographical area into the votes of the at-large area generally. Comment, Vote Dilution, Discriminatory Results, and Proportional Representation: What is the Appropriate Remedy for $a$ Violation of Section 2 of the Voting Rights Act?, 32 UCLA L. REv. 1203, 1204 n.6 (1985). A multimember district is a variant of the at-large electoral district: While an at-large district may have only one representative, a multimember district must have several representatives. In the contest of racially polarized voting, the majority group in both systems can outvote a minority group and elect all the representatives of the district. Typically, a multimember district is larger in geography and population than a single-member district. If the at-large or multimember district were divided into single-member districts, the minority group might prevail in one or more single-member districts. The Supreme Court has repeatedly held that while at-large or multimember systems may tend to be discriminatory, these schemes are not per se unconstitutional See Rogers v. Lodge, 458 U.S. 613, 617 (1982); City of Mobile v. Bolden, 446 U.S. 55, 66 (1980); White v. Regester, 412 U.S. 755, 765 (1973).

5. 478 U.S. 30 (1986). Gingles involved a challenge by black voters in North Carolina under $\$ 2$ alleging that multimember state legislative districts impaired their ability to elect representatives of their choice. Prior to World War II, only one black had been elected to public office in North Carolina in this century. Id. at 40 . Indeed, prior to 1972, no black candidate had ever been elected from the seven districts challenged in this suit. Id. at 82 (App. B to plurality opinion of Brennan, J.).

6. The terms "racially polarized voting" and "racial bloc voting" will be used interchangeably throughout this Note, as they are in the Gingles opinion. 478 U.S. at 52 n.18. These terms will generally refer to a condition accurring when an identifiable group votes as a bloc to weaken the votes of another discrete and identifiable group. Racial bloc voting provides a means of distinguishing between real and ideal situations: Where race is not relevant, electoral cleavage lines will cross racial lines rather than track them. See Note, Geometry and Geography: Racial Gerrymandering and the Voting Rights Act, 94 YALE L.J. 189, 199 (1984).

7. 42 U.S.C. $\S 1973(1982)$.

8. 478 U.S. at 51 . 
brings us no closer to establishing a coherent jurisprudence of vote dilution.

In attempting to bring clarity to a complex area of civil rights law, the Court has raised a prickly but intriguing question that this Note can probe but scarcely answer. In Section I, this Note explores how the opinion of the Court has made identifying the minority-preferred candidate crucial to successful proof of a section 2 claim. Section II discusses the plurality's advocacy of a supposedly race-neutral definition of "minority preferred"; the Note then examines the fractured response of lower courts to this definition. The concurrences of Justices White and O'Connor suggest a more race-conscious approach to the definition, and in Section III, the Note analyzes the approach that follows from their opinions. Section IV offers an alternative approach to the identification of the minoritypreferred candidate, an approach which addresses the concerns of Congress and Justice Brennan while maintaining a more flexible format.

\section{The Emerging Importance of the "Minority-Preferred Candidate"}

Thornburg v. Gingles was the Supreme Court's first attempt to clarify the results standard under the amended section $2 .{ }^{\circ}$ Unfortunately, the case produced four separate opinions, and the complicated web of dissents, concurrences, and plurality opinions ${ }^{10}$ has generated confusion in the lower courts.

Gingles did result in an opinion of the Court, which succeeded in narrowing the focus of the section 2 inquiry by means of a tripartite threshold test. In order to prove that an electoral system dilutes her vote, a plaintiff must prove the following:

First, the minority group must be able to demonstrate that it is sufficiently large and geographically compact to constitute a majority in a

9. Congress had amended $\S 2$ in response to City of Mobile v. Bolden, 446 U.S. 55 (1980), in which a sharply divided Supreme Court held that the Voting Rights Act required plaintiffs to demonstrate intentional discrimination. Congress was dissatisfied with the Mobile intent test for three reasons. First, it asked the wrong question by requiring an inquiry into the motives of officials who created a particular voting scheme or system, when the more appropriate inquiry was whether a minority group had equal access to the electoral process. Second, the intent standard was unnecessarily divisive because it inherently leveled charges of racism at officials or entire communities. Third, the intent standard was a difficult, often impossible burden for plaintiffs to carry. See Comment, The Results Test, supra note 4, at 296-97; S. REP. No. 417, supra note 3, at 36, reprinted in 1982 U.S. Code CoNG. \& ADMIN. NEwS 177, 214.

10. Four Justices wrote separate opinions in Gingles. Justice Brennan wrote the opinion of the Court, which included Parts I, II, III-A, III-B, IV-A, and V. Part III-C of Justice Brennan's opinion was joined only by Justices Marshall, Blackmun, and Stevens. Justice White joined the Opinion of the Court and concurred in Part IV-B of Justice Brennan's opinion, but also wrote a separate concurrence to express his disagreement with Part III-C. Justice O'Connor wrote separately to express her reasons for concurring only in the judgment of the Court; Chief Justice Burger, and Justices Rehnquist and Powell, joined her opinion. Justice Stevens wrote an opinion concurring in part and dissenting in part, which was joined by Justices Marshall and Blackmun. 
single-member district. . . . Second, the minority group must be able to show that it is politically cohesive. . . . Third, the minority must be able to demonstrate that the white majority votes sufficiently as a bloc to enable it . . . usually to defeat the minority's preferred candidate. ${ }^{11}$

The Court suggested that one way of establishing the latter two criteria would be to introduce evidence on the existence of racially polarized voting. ${ }^{12}$ As to what quantity, quality, or degree of racially polarized voting would satisfy the test, the Court remained mute, acknowledging only that "there is no.simple doctrinal test for the existence of legally significant racial bloc voting."13 Eschewing specifics in favor of a more flexible standard, the Court stated that the degree of bloc voting that constitutes "the threshold of legal significance"14 is necessarily fact-specific. ${ }^{15}$ The Court suggested, however, that the question requires an inquiry into minority and white voting patterns, ${ }^{16}$ and that a sustained pattern of racial bloc voting is more indicative of legally significant polarization than are the results of a single election. ${ }^{17}$

At this point, an observer might well ask, "Given this standard, why is the minority-preferred candidate important?" The answer lies in the peculiar problem of section 2 renvoi: to prove that the minority-preferred candidates are usually defeated, the section 2 plaintiff must first know who the minority-preferred candidates are. In order to meet the tripartite test, a plaintiff must introduce evidence of racially polarized voting. The clearest, most dramatic (and often the only) evidence of racially polarized voting is election or primary results, preferably covering several years. The plaintiff will want to use this evidence to demonstrate that whenever the minority community sponsored a candidate, that candidate was defeated by white bloc voting.

But in order to prove white bloc voting, the plaintiff must first decide which elections to include in her statistical proof. As one court recently noted, "Ascertaining whether legally significant white bloc voting exists begins with the identification of the minority members' 'preferred candidates' or 'representatives of their choice.' "18 Naturally, the plaintiff will

11. 478 U.S. at $50-51$.

12. Id. at 56 .

13. Id. at 58 .

14. Id. at 55 .

15. Id. at 55-56.

16. Id. at 56. Elaborating on this contention, the Court further suggested that "in general, a white bloc vote that normally will defeat the combined strength of minority support plus white 'crossover' votes rises to the level of legally significant white bloc voting." Id.

17. Id. at 57 .

18. Collins v. City of Norfolk, 883 F.2d 1232, 1237 (4th Cir. 1989). The checkered history of Collins typifies the complex evolution of $\S 2$ case law. See Collins v. City of Norfolk, 605 F. Supp. 377 (E.D. Va. 1984), affd, 768 F.2d 572 (4th Cir. 1985), vacated and remanded, 478 U.S. 1016 (1986), rev'd and remanded, 816 F.2d 932 (4th Cir. 1987), on remand, 679 F. Supp. 557 (E.D. Va. 
only want to include those elections that involve the minority-preferred candidate.

A quick example should show why: Assume that in Whoville, a community with a white majority (sixty percent) and a black minority (forty percent) of voters, and where state representatives are elected at-large, only ten elections have taken place since the at-large election system was instituted. Each election involved two candidates. In three of those elections, the black community united behind a single candidate, such that he won ninety-eight percent of the votes in the black community. Nonetheless, each of these candidates lost because the other candidate garnered an overwhelming percentage of the white vote. A court that examined just those elections might well conclude that voting in Whoville tracks racial lines.

But suppose that in the seven other elections no candidate enjoyed solid black support, and neither of the two candidates who ran claimed to represent the interests of the black community. A much smaller percentage of the black community (say, twenty percent) voted in these seven elections, and in five of the seven elections, the candidate who earned more of the black vote won the race. Should the court examine those elections as well? Certainly black voters may have voted in those elections, but does that fact alone-the fact that a certain candidate won some percentage, or even a majority, of the black vote-render that candidate the "minoritypreferred candidate"? If a judge examined all ten elections for racially polarized voting, she could easily conclude that, on balance, racially polarized voting was not a characteristic of Whoville elections.

As this example illustrates, the tripartite test makes the definition of the minority-preferred candidate a crucial determinant in a section 2 claim. Judges recognize that a claim may stand or fall on that determination, that "[t]he proper identification of minority voters' 'representatives of their choice' is critical."19 Short of commissioning a voter opinion poll (which would have its own methodological problems), what empirical measures can a judge rely on in making this determination? The fractured opinions in Gingles have provided little guidance to the lower courts, particularly on the issue that proved most divisive to the Supreme Court: whether a judge can consider the race of the candidates in determining who, if anyone, is the minority-preferred candidate. 


\section{The Brennan Approach: Race as an Irrelevancy}

\section{A. The Brennan Plurality Opinion}

In his plurality opinion, Justice Brennan considered and rejected the idea that the race of the candidate should play a role in determining the minority-preferred candidate. Justice Brennan contended that "both the language of $\S 2$ and a functional understanding of the phenomenon of vote dilution mandate the conclusion that the race of the candidate per se is irrelevant to racial bloc voting analysis." ${ }^{20}$ After all, section 2 does not specify that the candidate of choice must himself be a member of the minority group alleging vote dilution, and the term "vote dilution" describes a political phenomenon that may be wholly unconnected to race. ${ }^{21}$ Therefore, "it is the status of the candidate as the chosen representative of a particular racial group, not the race of the candidate, that is important.",22

Justice Brennan noted that "[b]ecause both minority and majority voters often select members of their own race as their preferred representatives, it will frequently be the case that a black candidate is the choice of blacks, while a white candidate is the choice of whites." ${ }^{23}$ Indeed, the facts of Gingles amply demonstrated this tendency:

The [three-judge district] court also reported its findings, both in tabulated numerical form and in written form, that a high percentage of black voters regularly supported black candidates and that most white voters were extremely reluctant to vote for black candidates. ${ }^{24}$

Yet Justice Brennan insisted that the frequent correlation between the race of the voter and the race of the candidate was not relevant to a section 2 inquiry. ${ }^{25}$

Justice Brennan's plurality opinion has provoked strong disagreement, both on the Court and in the circuits. Complaints center less on the methodological feasibility ${ }^{26}$ of Brennan's approach, and more on the fact that it bears little relation to common political experience.

\footnotetext{
20. 478 U.S. at 67.

21. See supra note 4 and infra note 26 .

22. 478 U.S. at 68 (emphasis in original).

23. Id.

24. Id. at 54; see also id. at 59 ("In all but 5 of 16 primary elections, black support for black candidates ranged between $71 \%$ and $92 \%$. . . [O]n average, $81.7 \%$ of white voters did not vote for any black candidate in the primary elections.").

25. "[T] he fact that race of voter and race of candidate is often correlated is not directly pertinent to a $\$ 2$ inquiry." Id. at 68 .

26. At first glance, the opinion of the Court appears to imply the relevance of race to a $\$ 2$ inquiry by setting up a tripartite test that relies heavily on proof of racially polarized voting. Intuitively, the determination of majority bloc voting would seem impossible in elections in which both candidates are of the same race, particularly since ballots are not coded by the race of the voter. But although statisticians cannot penetrate the secrecy of the ballot box, they can match available racial
} 


\section{B. Criticism of the Race-Neutral Approach}

Justice Brennan's approach carries an almost moral appeal, with the gloss of liberal academia. As commentators have noted, "there is no foundation in case law for the view that only a black candidate can represent black interests." ${ }^{27}$ However, Justice Brennan's approach falters under the glare of practical political experience. Taken alone, Justice Brennan's insistence on the irrelevance of the race of the candidate posits a world in which members of the white majority are not only capable of ably representing minority communities, but are also willing to do so. In this idealized world, no one need grapple with the dark history of disenfranchisement and alienation from the political process of one community at the hands of another. ${ }^{28}$ Nor, in this world, does the minority community con-

data (usually voting age population or percentage registered) to returns by electoral precinct. In homogeneous precinct analysis, a statistician examines the election returns for only those precincts which are homogeneous, and then extrapolates her results to the racial population as a whole. Many analysts consider a precinct homogeneous if over 90 percent of the population, voting age population, or registered voters residing in the precinct are black (or white). See Engstrom \& McDonald, Quantitatit' Eridence in Vote Dilution Litigation: Political Participation and Polarized Voting, 17 URB. LAw. 369, 371 (1985); Grofman, Migalski \& Noviello, The "Totality of Circumstances Test" in Stctom 2 of the 1982 Extension of the Voting Rights Act: A Social Science Perspective, 7 LAw \& Pol'y 199, 203 (1985). Indeed, Grofman explicitly notes that "[r]acially polarized voting may also occur in elections in which all candidates are of the same race, if the level of support for the various candidates varies significantly with the racial composition of the electorate." Id. at $219 \mathrm{n} .14$. Thus the question is not whether it is feasible to exclude race as a factor, but rather whether we further legislative intent by adopting a per se rule like Justice Brennan's.

27. Jacabs \& O'Rourke, Racial Polarization in Vote Dilution Cases Under Section 2 of the Voting Rights Act: The Impact of Thornburg v. Gingles, 3 J.L. \& PoL. 295, 349 (1986). In contrast, Justice Brennan's formulation emerges with basis in precedent: As recently as Whitcomb v. Chavis, 403 U.S. 124 (1971), the Supreme Court rejected a vote dilution claim in part because the plaintiffs, black residents of Indianapolis, had offered no proof that the suburban whites consistently elected could not adequately represent them. Id. at 154-55; see Eades, Section 2 of the Voting Rights Act: An Approach to the Results Test, 39 VAND. L. Rev. 139, 145 (1986). Indeed, in his dissent in Wright v. Rockefeller, 376 U.S 52 (1964), Justice Douglas argued that the government has no interest in defining political groups according to racial characteristics:

The principle of equality is at war with the notion that District A must be represented by a Negro, as it is with the notion that District B must be represented by a Caucasian, District C by a Jew, District $D$ by a Catholic, and so on . . . . That system, by whatever name it is called, is a divisive force in a community, emphasizing differences between candidates and voters that are irrelevant in the constitutional sense. Of course race, like religion, plays an important role in the choices which individual vaters make from among various candidates. But government has no business designing electoral districts along racial or religious lines.

When racial or religious lines are drawn by the State, the multiracial, multireligious communities that our Constitution seeks to weld together as one become separatist; antagonisms that relate to race or to religion rather than to political issues are generated; communities seek not the best representative but the best racial or religious partisan. Since that system is at war with the democratic ideal, it should find no footing here.

Id. at 66-67 (footnotes omitted); see also Blumstein, Defining and Proting Race Discrimination: Perspectives on the Purpose v's. Results Approach From the Voting Rights Act, 69 VA. L. REv. 633, 712-13 (1983) (endorsing Douglas' position).

28. For instance, the district court in Collins 2 . City of Norfolk found that the Virginia Constitution of 1902 effectively disenfranchised the black voters of Norfolk, and that from 1918 until 1968, every member of Norfolk's city council was white. Collins v. City of Norfolk, 605 F. Supp. 377, 382-83 (E.D. Va. 1984), aff d, 768 F.2d 572 (4th Cir. 1985), tracated and remanded, 478 U.S. 1016 (1986), rev'd and remanded, 816 F.2d 932 (4th Cir. 1987), on remand, 679 F. Supp. 557 (E.D. Va. 1988), n'd and renanded, 883 F.2d 1232 (4th Cir. 1989). And in McNeil v. City of Springfield, 
tend with years of experience of representation by members of the white majority, and the impact of that representation on levels of city sanitation, education, and health services. ${ }^{29}$

Analysts have noted and commented upon the results of this experience: "Usually, but not necessarily, the key differences in minority and nonminority voting patterns are found in high rates of 'own-race' voting in contests where there are candidates of more than one race (or linguistic grouping)." ${ }^{30}$ Indeed, in Gingles itself, the district court reviewed statistical data from fifty-three elections involving black candidates in all of the challenged districts, and concluded that black voters usually supported black candidates and white voters rarely supported the black voters' candidate of choice. ${ }^{31}$ Why, then, should judges assume that black voters will necessarily have any greater faith that white candidates can adequately represent the black community's interests? In short, Justice Brennan's plurality posits a cleaner, neater world than the one most section 2 plaintiffs inhabit. And to the extent that his assumptions fly in the face of social experience, judges of the lower courts should reject them.

\section{The Circuit Split}

While some courts have embraced Justice Brennan's approach, others-notably the Fifth Gircuit-have rejected it outright because of its practical consequences. Disagreement over Justice Brennan's approach has caused the circuits to split over a basic evidentiary issue: whether to accept statistics on all elections, or whether to focus on or accept only statistics from those elections that included a black candidate. While defendants argue for the former rule, plaintiffs usually argue for the latter. This issue has proven particularly trying for the courts, since they recognize that the choice of the data set often mandates the conclusions reached..$^{32}$ For instance, in Buchanan v. City of Jackson, ${ }^{33}$ the defendant's

658 F. Supp. 1015, 1020 (C.D. Ill. 1987), no black candidate had been elected to the Springfield, Illinois, City Council since 1911.

29. In fact, past discrimination in the provision of education, health, and employment are factors which Congress expected the courts to consider in evaluating a $\$ 2$ claim. See S. REP. No. 417, supra note 3. Accordingly, the district court in Citizens for a Better Gretna v. Gity of Gretna, 636 F. Supp. 1113 (E.D. La. 1986), affd, 834 F.2d 496 (5th Cir. 1987), cert. denied, 109 S. Ct. 3213 (1989), made detailed findings on conditions in Gretna, noting that the city's history of official discrimination in voting, housing, and education had lingering effects on the city's black population: Housing had remained segregated, and almost four times more blacks than whites lived below the poverty level in 1980. 636 F. Supp. at 1116-20.

30. Grofman, Migalski \& Noviello, supra note 26, at 203.

31. 478 U.S. at 54.

32. See Martin v. Allain, 658 F. Supp. 1183, 1193 (S.D. Miss. 1987) (noting discrepancy in determinations of racially polarized voting caused by differences in electoral sample). In Bradford County NAACP v. Gity of Starke, 712 F. Supp. 1523, 1531-34 (M.D. Fla. 1989), the defendant's expert witness examined 93 elections between 1968 and 1988, while the plaintiff's expert looked at the 15 elections since 1968 in which a black candidate ran. The court disregarded the testimony of the defendant's expert, because it concluded that the sample of elections analyzed was skewed in favor of reaching the conclusions that he drew. $I d$. at 1534 . 
expert witness argued that on the basis of his calculations, black voters had been able to elect candidates of their choice; he analyzed all elections since 1967, whereas the plaintiff's expert analyzed only those races involving black candidates and white candidates since 1975. The court noted that on the basis of these different sets of data, the two experts reached different conclusions as to the existence of racial polarization. ${ }^{34}$

The responses of the circuit courts on this issue have ranged from acceptance to outright rejection. At one extreme, the Eleventh Circuit apparently has adopted Justice Brennan's plurality opinion; ${ }^{36}$ the Tenth Circuit, ${ }^{36}$ and one district court of the Seventh Circuit, ${ }^{37}$ appear to have done so as well. In the Tenth Circuit decision, ${ }^{38}$ the court concluded

that there is no rule of law prohibiting the district court from examining those elections having only Anglo candidates. Such elections may be relevant and can be used to discern whether racially polarized voting exists and to measure the success of minority preferred candidates, so long as one of the Anglo candidates can be considered a preferred candidate of the minority group. ${ }^{38}$

In an effort to hold the middle ground, district courts of the Sixth Circuit have held that the judges may consider all elections, but may give additional weight to those involving minority candidates. ${ }^{40}$

In marked contrast, the Fifth Circuit has firmly rejected Justice Brennan's approach by focusing on those elections in which black candidates

33. 683 F. Supp. 1515 (W.D. Tenn. 1988).

34. Id. at 1529 .

35. Carrollton Branch of NAACP v. Stallings, 829 F.2d 1547, 1557 (11th Cir. 1987), cert. demed sub nom. Duncan v. Carrollton Branch of NAACP, 485 U.S. 936 (1988). But here the rampant confusion may have spawned a split within a circuit as well. In Bradford County $N A A C P, 712 \mathrm{~F}$. Supp. at $1540 \mathrm{n} .24$, the district court noted the absence of binding precedent on this issue, and decided that its own reading of the recent case of Solomon v. Liberty County, 865 F.2d 1566 (11th Cir. 1988), z'acaled, 873 F.2d 248 (11th Cir. 1989), supported the decision to exclude the defendant's whiteversus-white election data from consideration.

36. Sanchez v. Bond, 875 F.2d 1488, 1495 (10th Cir. 1989).

37. In Williams v. State Board of Elections, 696 F. Supp. 1574 (N.D. Ill. 1988), the court stated:

In their memorandum, the plaintiffs assert the following: "In the words of the Court in

Thornburg, minority political cohesiveness means 'blacks vote for blacks." "The Supreme

Court made no such statement in Thornburg $v$. Gingles. The problem with plaintiffs' asser-

tion is not just its inaccuracy; it also reveals plaintiffs' misinterpretation of Gingles. Under

Gingles, political cohesiveness means that minorities vote as a block, not that they vote for candidates who belong to their racial or ethnic group.

Ih. at 1580 (citation omitted).

38. Sanchez, 875 F.2d at 1488.

39. Id. at 1495.

40. See Buchanan v. City of Jackson, 683 F. Supp. 1515,1529 (W.D. Tenn. 1988) ("Clearly, the court may consider all elections in determining whether members of a minority have less opportunity than other members of the electorate to elect representatives of their choice. . . That is not to say, however, that all elections must be given equal weight. . .."); id. at 1531 ("elections in which there was a black candidate are more probative"); accord Mallory v. Eyrich, 707 F. Supp. 947, 952 (S.D. Ohio 1989) ("elections in which minority candidates have participated are more probative of racial polarization"). 
participated. ${ }^{41}$ As the district court stated clearly in Citizens for a Better Gretna v. City of Gretna: ${ }^{42}$

Unless it can be shown that an election occurred in which a white candidate ran on issues strongly affecting the black community and with an open, positive and strong identification with the black community-which has not been shown in this matter-candidacies of black persons are the proper focus of inquiry concerning the extent to which elections are polarized. ${ }^{48}$

In so holding, the Fifth Circuit confronted the underlying question in the identification of the minority-preferred candidate: What showing of proof would courts require in order to recognize white candidates as "minoritypreferred"?

Certainly some courts have required no proof beyond a showing of black support. For instance, the district court in Collins v. City of Norfolk $^{44}$ held that " $[\mathrm{m}]$ ore than half of all candidates receiving majority black support have been elected in the past eighteen years." the district court, the circuit court noted that the successful candidates were generally white, and that in several instances, the candidates elected did not even regard themselves as the black community's representative of choice. ${ }^{46}$ Similarly, the court in Sanchez $v$. Bond ${ }^{47}$ affirmed the trial court's conclusion that "several Anglo county commissioners had in fact been the preferred candidates of Hispanics." waffled on the issue.48

Only the Fifth Circuit has acknowledged the troubling aspect of designating a white candidate as "minority-preferred"-the fear that in so doing, courts will fail to recognize those situations in which neither candidate was the candidate "of choice." For instance, political impediments,

41. See Campos v. City of Baytown, 840 F.2d 1240, 1245 (5th Cir. 1988), cert. denied, 109 S. Ct. 3213 (1989); Dillard v. Baldwin County Bd. of Educ., 686 F. Supp. 1459, 1465 (M.D. Ala. 1988); Citizens for a Better Gretna v. City of Gretna, 636 F. Supp. 1113, 1133 (E.D. La. 1986), affd, 834 F.2d 496 (5th Cir. 1987), cert. denied, 109 S. Ct. 3213 (1989); see also Gunn v. Chickasaw County, 705 F. Supp. 315,319 n.1 (N.D. Miss. 1989) ("II]t is unfortunately practical usually to consider only the success of black candidates, though it is entirely likely that black voters have and will unite in support of non-black candidates.").

42. 636 F. Supp. at 1133 .

43. Id.

44. 679 F. Supp. 557 (E.D. Va. 1988), rev'd and remanded, 883 F.2d 1232 (4th Cir. 1989).

45. Id. at 572 .

46. Collins v. Gity of Norfolk, 883 F.2d 1232, 1239-40 (4th Cir. 1989).

47. 875 F.2d 1488 (10th Cir. 1989).

48. Id. at 1492 .

49. For instance, in Smith v. Clinton, 687 F. Supp. 1310 (E.D. Ark. 1988), the court stated, "Certainly, there is evidence that white candidates preferred by black voters sometimes win in elections involving only whites." Id. at 1317. The court did not, however, explain what it would do with such evidence as a general rule; the court noted only that in this case, evidence of polarized voting in black-white elections was so strong "that it cannot be overcome even when all reasonable inferences are accorded to the evidence of elections involving only white candidates." Id. 
such as slating processes and endorsements by incumbents, may artificially constrain the field of candidates. ${ }^{50}$ The experience of confronting such obstacles may alienate minority candidates and dissuade them from running for office. Consistently constrained choices may contribute to apathy among minority voters: At least one court has noted that black turnout declines when only white candidates run. ${ }^{81}$ Thus if some blacks do choose to vote in a white versus white election, should their choice automatically be deemed "minority-preferred," if that term means designated and supported by the minority community?

The district court in Gretna ${ }^{62}$ responded with an emphatic "No." In that case, although no black person had been elected alderman in Gretna since the city's incorporation, the defendant nonetheless argued that "black citizens have elected candidates of their choice . . . with regularity because Gretna's white officials have always received a significant portion of the black vote and the support of Gretna's black political organizations." 53 The court called that argument "spurious at best." the circuit court affirmed, holding that "Gingles is properly interpreted to hold that the race of the candidate is in general of less significance than the race of the voter-but only within the context of an election that offers voters the choice of supporting a viable minority candidate." $v$. City of Baytown, ${ }^{56}$ the court rejected an argument similar to the defendant's argument in Gretna, this time made by a defendant who claimed that "anytime a candidate gets a majority of the minority votes he is the 'chosen representative' of the minority group."'37 Instead, the court held

50. Note, The Constitutional Significance of the Discriminatory Effect for At-Large Elections, 91 YALE L.J. 974, 990-91 (1982). For instance, plaintiffs in Williams v. State Bd. of Elections, 718 F. Supp. 1324 (N.D. Ill. 1989), argued that "[t]hey are required to choose among candidates foisted upon them by the Democratic slate-makers without regard to the interests or preferences of the black and Hispanic communities." Id. at 1326.

51. McMillan v. Escambia County, 638 F.2d 1239, 1242 n.6 (5th Cir.), appeal dismissed sub nom. City of Pensacola v. Jenkins, 453 U.S. 946 (1981) (case settled). Another court noted that a larger percentage of the total population is likely to vote in an election in which a minority is running. League of United Latin Am. Citizens v. Midland Indep. School Dist., 648 F. Supp. 596, 601 (W.D. Tex. 1986), affd, 829 F.2d 546 (5th Cir. 1987).

52. Citizens for a Better Gretna v. City of Gretna, 636 F. Supp. 1113 (E.D. La. 1986), affd, 834 F.2d 496 (5th Cir. 1987), cert. denied, 109 S. Ct. 3213 (1989).

53. Id. at 1121 .

54. The court then quoted a passage which amply demonstrates the artificial nature of constrained choice:

At first it was possible to buy Model $T$ touring cars that were painted red and roadsters that were painted gray, but in mid-1909, under pressure to build as many cars as possible, the color for all Model Ts became dark green with black trim and red striping. In 1912, with demand for the car still rising and the urgent need for even greater standardization and simplification, Ford made this famous statement, "Any customer can have a car painted any color he wants so long as it is black." Thereafter, only black cars poured out of the Highland Park factory.

J. Barry, Henry Ford and Mass Production 55 (1973), quoted in 636 F. Supp. at 1121.

55. 834 F.2d at 503.

56. 840 F.2d 1240 (5th Cir. 1988), cert. denied, 109 S. Ct. 3213 (1989).

57. Id. at 1245 . 
that there was "no evidence that any Anglo-Anglo race . . . offered the voters the choice of a 'viable minority candidate." "\$8 One court, following in the wake of Gretna and Campos, rejected the practical consequences of such arguments by defendants: "Section 2 was not designed, nor will it be construed, to provide minority groups the ability to participate equally in the electoral process and to have the opportunity to elect representatives only if those candidates are white."

Thus, the response to Justice Brennan's definition has run the gamut, from acceptance of his race-neutral suggestion to rejection of his definition as inconsistent with its result. Compounding the confusion has been the factual basis for the Gingles decision itself. Given Justice Brennan's assertion that the race of the candidate is not relevant, a full examination of the political process would seem to require not only an assessment of how black-supported candidates fared in the elections, but also how blacksupported white candidates did. Yet neither the lower court opinion nor Justice Brennan's opinion mentions any such candidates. ${ }^{60}$ This discrepancy has not escaped the notice of other courts. ${ }^{61}$

\section{The White and O'Connor Approaches: Race as One of MANY FaCTORS}

\section{A. The White and O'Connor Concurrences}

Both Justices White and O'Connor reject outright Justice Brennan's approach to identifying the minority-preferred candidate. In his brief concurrence, Justice White criticized the Brennan plurality opinion as "interest-group politics rather than a rule hedging against racial discrimination." ${ }^{62}$ Justice White noted that under this test, polarized voting results whenever the majority of white voters votes for different candidates than the majority of the blacks. Justice White then presented the following two hypotheticals:

Suppose an eight-member multimember district that is $60 \%$ white and $40 \%$ black, the blacks being geographically located so that two safe black single-member districts could be drawn. Suppose further

58. Id.

59. East Jefferson Coalition v. Jefferson Parish, 691 F. Supp. 991, 1001 (E.D. La. 1988); see also Westwego Citizens for Better Gov't v. City of Westwego, 872 F.2d 1201, 1208 n.7 (5th Cir. 1989) (remanding for further findings of fact and conclusions of law; "Evidence of black support for white candidates in an all-white field, however, tells us nothing about the tendency of white bloc voting to defeat black candidates." (citation omitted)).

60. See Jacobs \& O'Rourke, supra note 27 , at 349.

61. See Citizens for a Better Gretna v. City of Gretna, 834 F.2d 496, 503-04 (5th Cir. 1987) ("The various Gingles concurring and dissenting opinions do not consider evidence of elections in which only whites were candidates. Hence, neither do we."), cert. denied, 109 S. Ct. 3213 (1989); Campos, 840 F.2d at 1245 ("Gingles itself looked only to elections where Black candidates were running.").

62. 478 U.S. at 83. 
that there are six white and two black Democrats running against six white and two black Republicans. Under Justice Brennan's test, there would be polarized voting and a likely $\S 2$ violation if all the Republicans, including the two blacks, are elected, and $80 \%$ of the blacks in the predominantly black areas vote Democratic. I take it that there would also be a violation in a single-member district that is $60 \%$ black, but enough of the blacks vote with the whites to elect a black candidate who is not the choice of the majority of black voters. ${ }^{63}$

Thus Justice White appears to be concerned with the prospect that plaintiffs can and will allege section 2 violations whenever their preferred candidate loses for reasons unconnected with race-in other words, for reasons such as party affiliation, electoral experience, or even socioeconomic status. ${ }^{\text {ex }}$

It is a very small step from Justice White's concerns to the suggestion that these additional explanatory factors should enter the vote dilution inquiry. Although Justice White does not make this suggestion, Justice O'Connor explicitly does. In fact, it forms the core of her disagreement with Justice Brennan. Although she acknowledged that such evidence cannot rebut a showing of racially polarized voting, Justice O'Connor noted that such evidence may bear on whether the majority bloc will consistently defeat minority candidates, or whether "another candidate, equally preferred by the minority group, might be able to attract greater white support in future elections." ${ }^{85}$ Thus, although both Justices would apparently allow consideration of the race of the candidate in identifying the minority-preferred candidate, they are hunting bigger game-namely, introducing all potentially relevant variables into the section 2 inquiry.

\section{B. Criticism of the Race-Conscious Approach}

At least one court has described Justice O'Connor's concurrence as more persuasive than the other Gingles opinions. ${ }^{66}$ But not unexpectedly, the most compelling criticism of the White/O'Connor approach derives not from its stance on the race of the candidate, but from the logical consequences of Justice O'Connor's argument. Under Justice O'Connor's approach, a defendant could always find some variable that would explain

63. Id.

64. In the situation described, Justice White seems to fear that Justice Brennan's formulation confers a "right to win" upon the minority candidate and her constituency, rather than the right to a "level political playing ground." In contrast, commentators have described the whole Gingles decision as "only protect[ing] the right of the minority-preferred candidate to run for public office without the white resisters unfairly diluting the candidate's opportunity for success." LeVarsky, Fair and Effectite Voting Strength Under Section 2 of the Voting Rights Act: The Impact of Thornburg v. Gingles on Minority Vole Dilution Litigation, 34 WAYNE L. REv. 303, 325 (1987).

65. 478 U.S. at 100.

66. Collins v. City of Norfolk, 816 F.2d 932, 936 n.3 (4th Cir. 1987), on remand, 679 F. Supp. 557 (E.D. Va. 1988), rei'd and remanded, 883 F.2d 1232 (4th Cir. 1989). 
why the white majority failed to vote for a minority candidate, and could always argue that once the community began fielding more experienced candidates, or more ideologically acceptable candidates, the majority bloc would respond favorably. But section 2 does not condition the opportunity to elect a preferred representative on the whim of the majority voting bloc. ${ }^{67}$ As the Gretna court has stated in a related context, "If participation is to be labeled 'effective,' then it certainly must be a matter of right, and not a function of grace." ${ }^{\prime 88}$ Moreover, Justice O'Connor's argument traps plaintiffs in a vicious circle: The white bloc voters may reject their minority-supported candidates because they "lack experience," but the candidates have to get elected in order to earn that experience. ${ }^{6 \theta}$

Even more disturbing are the prospects for lower courts that examine the full range of explanatory variables contemplated by Justice O'Connor in order to identify the minority-preferred candidate. Courts would then have the discretion to decide who was the minority-preferred candidate on the grounds of ideology, party affiliation, or even education $;^{70}$ this would usher courts into the dangerous realm of divining the minority-preferred candidate on the basis of the judge's conception of the prevalent political ideology of a potentially diverse, even fractured, minority community. ${ }^{71}$

Although disturbing, the opinions of Justices O'Connor and White are not unexpected; Justice White's opinion, at least, is largely consistent with views he has expressed in the past. ${ }^{72}$ In contrast, Justice Brennan's definition marks a significant departure from his earlier jurisprudence. Given Justice Brennan's acceptance of race-consciousness in other areas of civil rights (such as race-conscious remedies), ${ }^{73}$ his contention that the race of the candidate is irrelevant in this context appears grossly inconsis-

67. Racially polarized voting often dictates the election of majority-approved representatives:

Where an overall pattern, albeit with exceptions, of racially polarized voting exists, only black candidates who have received the majority "seal of approval" can be elected. Black candidates must, under such circumstances, moderate their stands on issues of particular importance to blacks in order to gain the support of needed white voters.

Note, supra note 50, at 990 .

68. Citizens for a Better Gretna v. City of Gretna, 636 F. Supp. 1113, 1123 (E.D. La. 1986), affd, 834 F.2d 496 (5th Cir. 1987), cert. denied, 109 S. Ct. 3213 (1989).

69. The Supreme Court has already grappled with this issue in the context of jury selection. Ses Batson v. Kentucky, 476 U.S. 79, 106 (1986) (Marshall, J., concurring) ("Any prosecutor can easily assert facially neutral reasons for striking a juror, and trial courts are ill-equipped to second-guess those reasons.").

70. Collins, 883 F.2d at 1246 (Chapman, J., dissenting).

71. Indeed, Judge Chapman's dissent in Collins, 883 F.2d at 1246, raises several such concerns. Although Judge Chapman focuses on the danger of taking the race of the candidate into account, his grim forecast of "a litmus test for the political beliefs of minority preferred candidates. . . . (in which) there are 'proper' black political attitudes, and therefore under the Voting Rights Act some ideas are worth more than others," applies equally to the White/O'Connor approach. Id.

72. For example, in the majority opinion in United Jewish Org. v. Carey, 430 U.S. 144 (1977), Justice White upheld the use of racial classifications for the purpose of drawing district boundaries in compliance with $\S 5$ of the Voting Rights Act.

73. See Regents of the Univ. of Cal. v. Bakke, 438 U.S. 265, 344 (1978) (Brennan, J., concurring in part and dissenting in part) (affirming his support for "race-conscious action" to "accomplish the remedial objectives of Title VI"). 
tent-unless one perceives it as a "damming the floodgates" response to the suggestions of Justice O'Connor. As Justices White and O'Connor point out, it was unnecessary for the Court in Gingles to decide the relevance of the race of the candidate. ${ }^{74}$ Unnecessary, unless Justice Brennan is trying to forestall any attempt to import causation-and indirectly, intent-back into the vote dilution calculus. Justice Brennan repeatedly stated that "[i]t is the difference between the choices made by blacks and whites-not the reasons for that difference" that is important. ${ }^{78}$ Justice Brennan therefore explicitly rejected the defendant's argument in Gingles that the plaintiff must prove that factors other than the race of the voter did not "cause" the observed voting pattern; under such a "pernicious" standard, a plaintiff would fail to prove racial bloc voting whenever the black and white populations could be described in terms of other socioeconomic characteristics. ${ }^{77}$ Thus if Justice Brennan were to argue that the race of the candidate was relevant to the determination of the minoritypreferred candidate, he would be allowing the camel's nose under the tent; if he acknowledged that one variable was relevant, how could he keep the other variables out on any principled basis?

Given this alternative understanding of the many concerns that may underlie Justice Brennan's approach, does an effective response to those concerns mandate his broad definition of the minority-preferred candidate-or can we devise a more flexible approach?

\section{An Alternative Approach: Race as a Plus}

In devising a solution to this problem, we need not limit ourselves to the approaches suggested in Gingles; a variant, such as a modified race conscious approach, would utilize part of the White/O'Gonnor approach while adequately addressing Justice Brennan's concerns. Of course, the concerns of the three justices should not form the sole focus of attention. Congress has concerns of its own, as do section 2 plaintiffs and defendants. Congress clearly amended section 2 to ease the plaintiff's burden of proof, subject only to a caveat against an established right to proportional representation. Voting rights jurisprudence should reflect this intent to give plaintiffs every opportunity to prove their case. But Justice Brennan's plurality opinion, while advocating a color-blind approach to electoral

74. Sep 478 U.S. at 83 (White, J., concurring); id. at 101 (O'Connor, J., concurring).

75. Id. at 63 .

76. Id. at 64 .

77. Id. at 65. Similarly, under Justice White's formulation, the plaintiff's proof would fail whenever the black and white populations could be described in terms of political characteristics, such as party affiliation (Republican or Democrat). This formulation poses no less a problem, for racism and partisan motivation are often intertwined; as some commentators have noted, "Ruling factions attempt to rig elections against blacks in part because blacks tend to support political interests and candidates antithetical to the ruling factions." Howard \& Howard, The Dilemma of the Voting Rights ActRerognizing the Emerging Political Equality Norm, 83 Colum. L. Rev. 1615, 1644 (1983). 
data, does not always lead us to a race-neutral result: If the race of a candidate cannot be considered, then whenever black voters cast ballots for a nonblack candidate, that candidate can be designated the "minoritypreferred candidate," and can be so designated even if the majority of the black community boycotted the election or simply stayed away out of apathy or alienation. For instance, in the Whoville hypothetical posed in Section I, a judge who adheres to Justice Brennan's approach will conclude that because the minority-preferred candidate won fifty percent of all elections, the plaintiff has failed to prove the third prong of the Gingles test. ${ }^{78}$ Such a result unintentionally subverts the legislative intent of the amendment.

In contrast, Justices White and O'Connor argue that race is not always irrelevant to a section 2 inquiry. While their opinions may prove persuasive in a less race conscious future, their reasoning-like Justice Brennan's-assumes the existence of political systems less racially polarized than those most section 2 plaintiffs currently encounter. Racially polarized voting and interest group politics will remain difficult to distinguish as long as minority voters are disproportionately represented in lowerclass and working class society, or as long as minorities vote according to a specified political or social agenda.

While the opinions of Justices White and O'Connor may not reflect the political reality facing the potential section 2 plaintiff, their suggestion to consider the race of the candidate in the section 2 inquiry makes intuitive sense and would assist plaintiffs in proving their cases. For instance, the Whoville judge adopting a modified race conscious approach would recognize that the minority-preferred candidate won only thirty percent of all elections; the plaintiff would no longer be automatically eliminated by a numerical sleight-of-hand. Moreover, if we reject the reasoning of Justices White and O'Connor, a modified race conscious approach need not open the floodgates to consideration of variables such as education or party affiliation. More than one line of reasoning can lead us to accept the modified race conscious approach; the approach does not lose its utility if we reject one line of reasoning and accept another.

A modified race conscious approach could assume many forms. For instance, courts could focus solely on those elections with high minority voter turnout. Another practical modification would involve considering race a plus, as one additional factor, much as race or ethnic background may be deemed a plus in the "Harvard Plan" described by Justice Powell in Bakke. ${ }^{79}$ Thus a court could examine all elections, but would give additional weight to those elections involving black or hispanic candidates. The district court in Buchanan adopted a discretionary version of this

78. See supra text accompanying note 11.

79. 438 U.S. at 316-17. 
approach by suggesting that all elections need not be given equal weight. ${ }^{80}$ The Supreme Court could carry the Buchanan court's approach a step further by explicitly assigning additional weight to elections involving minority candidates. Weighting the consideration process would ease the plaintiff's burden without leading inevitably to the plaintiff's success-thus largely avoiding the congressionally-forbidden pitfall of proportional representation. Indeed, a modified race conscious approach would have some basis in precedent, for the Supreme Court has consistently upheld consideration of racial criteria at the remedy stage in voting rights cases. In United Jewish Organizations v. Carey, ${ }^{81}$ Justice White wrote that "[t]he permissible use of racial criteria is not confined to eliminating the effects of past discriminatory districting or apportionment."82 Justice Brennan wrote separately in Carey to express his concerns about the intended and unintended consequences of racial assignment, legitimate concerns which included the difficulties of determining whether the classification furthers illicit or benign objectives, and the potential stigmatizing effect of even a benign use of race. ${ }^{83}$ Nonetheless, even Justice Brennan's opinion "beg[a]n with the settled principle that not every remedial use of race is forbidden." 84 We could take Justice Brennan's Carey concerns into account by employing a weighting process which does not mandate a particular result.

Thus, cautious consideration of the race of the candidate as an additional, persuasive element would further the intent of section 2 by easing the plaintiff's burden of proof. Even without further elucidation by the Supreme Court, lower courts could utilize this straightforward approach. Considering race only as a plus would prevent this alternative from degenerating into a "racial piece-of-the-action approach" that would "encrust[] rather than exorcise[] the previous system of racial politics."

\section{ConClusion}

Congress cannot prevent people from casting their votes in accordance with their racial prejudices; Congress can prevent people from amplifying those prejudices through discriminatory voting practices and electoral schemes. This is the purpose of section 2-to afford plaintiffs an equal opportunity, no more, no less.

But Gingles has failed to further that intent: The confusion in Gingles has spawned further confusion and inconsistency in the interpretation and vindication of section 2 rights by the lower courts. In an attempt to lay to

80. Buchanan v. City of Jackson, 683 F. Supp. 1515, 1529 (W.D. Tenn. 1988).

81. 430 U.S. 144 (1977).

82. Id. at 161 (Justice Brennan joined this section of Justice White's opinion).

83. Id. at $172-73$ (Brennan, J., concurring in part).

84. Id. at 171 (Brennan, J., concurring in part).

85. Blumstein, supra note 27 , at 713 . 
rest the arguments over application of the results test, the Court touched off an even more difficult argument on the identification of the minoritypreferred candidate. However, allowing courts to consider the race of the candidate in identifying the minority-preferred candidate will further the intent of section 2, by forestalling legal codification of past electoral unfairness. 